COCOS (1997), 12, 39 - 43

Printed in Sri Lanka

\title{
CALLUS INDUCTION AND DIRECT SHOOT FORMATION IN IN VITRO CULTURED IMMATURE INFLORESCENCE TISSUES OF COCONUT
}

\author{
V R M Vidhana Arachchi and L K Weerakoon \\ Coconut Research Institute, Lunuwila, Sri Lanka
}

\begin{abstract}
Clonal propagation of elite palms is a promising possibility for producing uniform planting material and improving productivity in coconut lands. In the absence of a natural vegetative propagation method, in vitro culture remains the only approach for vegetative multiplication of coconut.

Immature inflorescence material has shown to be a promising source of explants for coconut tissue culture. In the present study, four different culture media (medium 72; modified Eeuwens $\mathrm{Y}_{3}$ medium; coconut anther culture medim; modified Blake's medium) were evaluated for callus induction in floral explants: Immature inflorescences were collected non-destructively from 12 year old Sri Lanka-tall coconut palms and rachilla segments obtained from these inflorescences were cultured on above media.
\end{abstract}

Out of the four culture media tested, callus production was observed only in the explants cultured on medium 72. In this medium (which contained $24 \mu \mathrm{M}$ 2,4-dichlorophenoxyacetic acid and $0.25 \%$ activated charcoal), about $30 \%$ of the floral explants produced compact, highly embryogenic calli. Direct regeneration of shoots from floral primordia occurred at a very low frequency in the modified Eeuwens $\mathrm{Y}_{3}$ medium which contained $200 \mu \mathrm{M}$ 2,4-dichlorophenoxyacetic acid and $0.2 \%$ activated charcoal. No callogenesis or direct organogenesis were observed in the floral explants cultured on the other two culture media tested.

\section{INTRODUCTION}

Coconut palms raised from seeds show a wide variation in the field due to their highly heterozygous nature. Vegetative multiplication of elite palms is a promising possilbility for producing uniform planting material of 
high quality. This would not only improve the productivity in coconut lands but also produce uniform parent material for breeding programmes. In vitro culture is the only channel open for intensive vegetative propagation of coconut and the development of a reliable in vitro cloning technique would also pave the way to genettc transformation of coconut by transfer of foreign genes that confer desirable characters.

Recent. studies on immature inflorescence culture of coconut have indicated that plant regeneration through somatic embryogenesis is possible but the technique has not yet been mastered (Verdeil et. al. 1994; Hornung, 1995). At the Coconut Research Institute, of Sri Lanka, work on clonal propagation has been done mainly with immature embryo (Karunaratne and Periyapperuma, 1989) and leaf explants (Kanunaratne et at 1991) and very little work has been done on inflorescence culture. Therefore, the present study was undertaken to assess the suitability of four different culture media for callus induction in immature inflorescence explants with a view to develop a reliable protocol for clonal propagation of coconut.

\section{Materials and methods}

Immature inflorescences of $8-10 \mathrm{~cm}$ outer spathe length were obtained non-destructively (Rillo, 1989) from 12 year old Sri Lanka-tall coconut palms. The inflorescences were surface sterilized for 15 minutes in $3 \%$ calcium hypochlorite solution followed by thorough rinsing with sterile distilled water. Then the outer and. inner spathes were removed under aseptic conditions. The top and basal portions of the inflorescence were discarded and only the middle portion of the inflorescence (about $3 \mathrm{~cm}$ in length ) was used for culturing. Rachilla was cut into 1-1.5 mm long sections and cultured into screw capped vials containing $15 \mathrm{ml}$ of culture medium. The following culture media were used in this study.

1. Medium 72 formulated by Karunaratne and Periyapperuma (1989) containing $24 \mu \mathrm{M}$ 2,4-dichlorophenoxyacetic acid (2,4-D) and $0.25 \%$ activated charcoal.

2. Modified Eeuwens $Y_{3}$ medium described by Verdeil et. al. (1994) containing $200 \mu \mathrm{M}$ 2,4-D and $0.2 \%$ activated charcoal.

3. Modified Blake's medium described by Ebert and Taylor (1990) containing $200 \mu \mathrm{M}$ 2,4-D and $0.25 \%$ activated charcoal. 
4. Coconut anther culture medium formulated by Tuyen and Guzman (1982) containing $10 \mu \mathrm{M} 2,4-\mathrm{D}, 10 \mu \mathrm{m}$ naphthaleneacetic acid and $0.25^{\circ}$ activated charcoal.

All the cultures were incubated in dark at $301 \mathrm{C}$.

\section{RESULTS}

The first sign of callogenesis (indicated by floral bud swelling) was observed in explants cultured on medium 72 (a medium developed for callus induction in immature embryo explants of coconut) after about 8 weeks of culturing. This was followed by the initiation of small, whitish calli from floral areas (Fig. 1). The callus tissues continued to grow into larger masses (without any subculturing) within 12-14 weeks of culturing (Fig. 2). About $30 \%$ of the cultured explants produced embryogenic calli (Fig. 3) on the above medium.

In modified Eeuwens $Y_{3}$ medium, transluscent outgrowths developed directly from the floral buds within 6 weeks of culturing. Some of these structures developed into shoots upon subculturing into a medium containing $8 \mu \mathrm{m}$ 6-benzylaminopurine and $10 \mu \mathrm{M}$ 2,4-D. However, the frequency of shoot regeneration was very low. Roots were induced on these shoots (Fig. 4) by dipping in $100 \mu \mathrm{M}$ indoleacetic acid solution for 3 days followed by culturing them in an auxin-free medium as described by Fernando and Gamage (1995):

\section{DISCUSSION}

In the present study, emphasis was placed on callogenesis in flower meristem explants as it is the first stage in the process of somatic embryogenesis. The results indicate that the culture medium developed for callogenesis in immature embryo explants of coconut is also suitable for callogenesis in floral explants. Work in progress is directed towards the induction of somatic embryogenesis in the calli obtained.

The direct shoct regeneration observed in modified Eeuwens Y3 medium is also of importance as it could lead to the development of a regeneration protocol devoid of a callus phase. Thus, attempts will be made to refine the culture conditions to increase the frequency of direct shoot formation. 


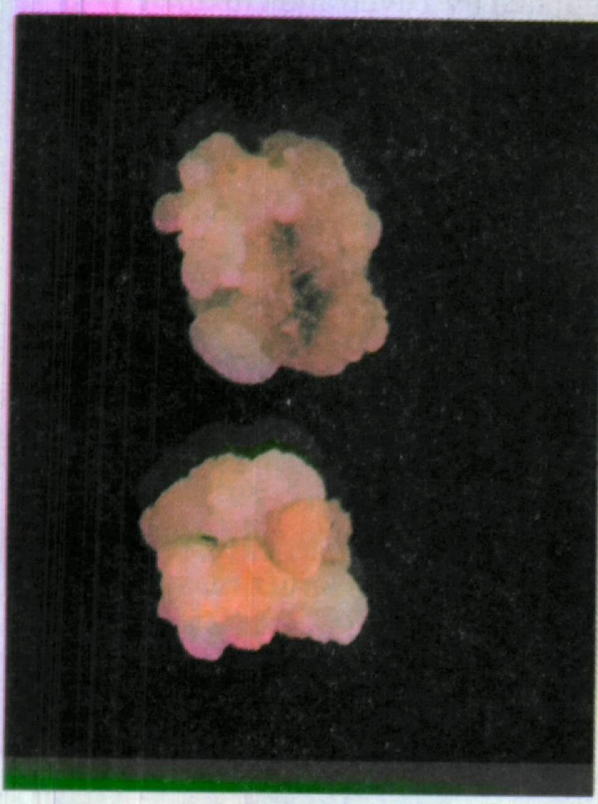

Fig. 1 ; Callus initiation on floral explants. ( $\times 3$ )

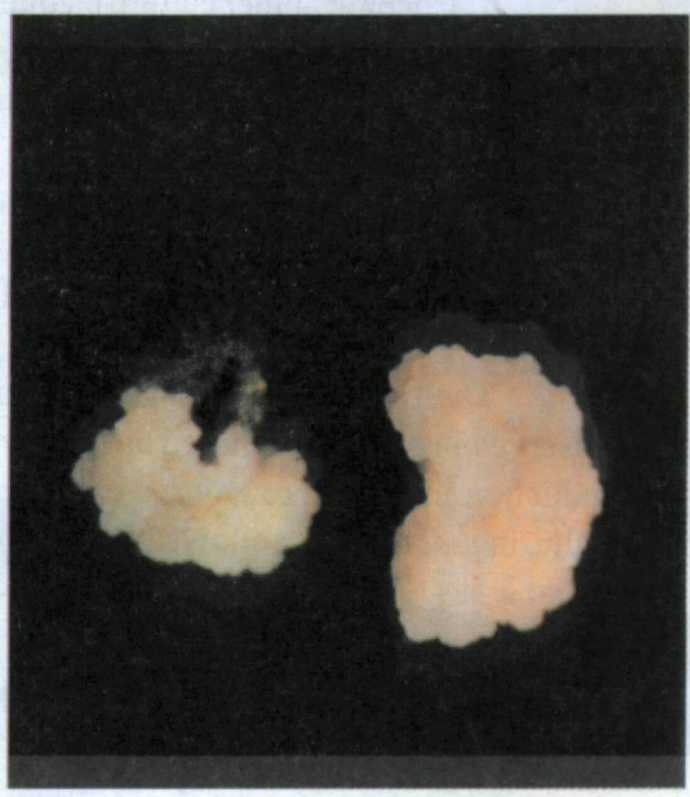

Fig. 2 : Nodular, embryogenic callus. (x 3)

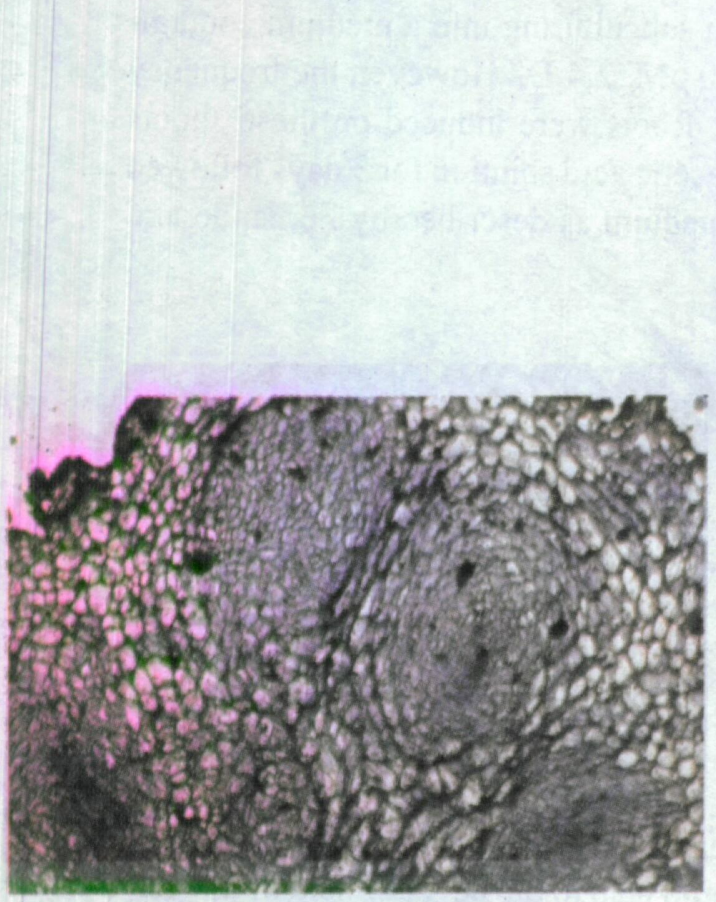

Fig. 3 : Histological cross section of an embryogenic callus showing meristematic centers. (MC) $(x$ 100)

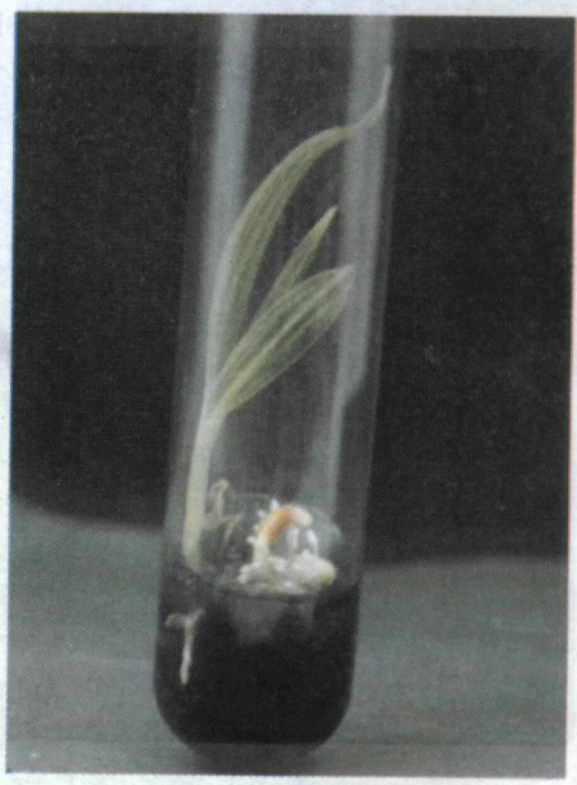

Fig. 4 : Formation of roots on a regenerated shoot. $(\times 0.7)$ 


\section{ACKNOWLEDGEMENTS}

We are most grateful to Mr. E. S. Shantha for his assistance in histological work. We also gidtetully acknowleoge the assistance of Mr. Pemsiri Silva and Mr. H.P. Asoka Kumara the photographers. Thanks are also due to the staff of Tissue Culture Division, Coconut Research Institute for their assistance in performing this investigation.

\section{References}

Ebert, A. and Taylor, H.F. (1990). Assessment of the changes of 2,4dichlorophenoxyacetic acid concentrations in plant tissue culture media in the presence of activated charcoal. Plant Cell Tissue and Organ culture 20: 165-172.

Fernando, S.C. and Gamage, C.K. (1995). Clonal propagation of coconut: Improved culture conditions for rhyzogenesis. COCOS 10: 20-25.

Hornung, H. (1995). Initiation of callogenesis in coconut palm (Cocos nucifera L.). In Lethal Yellowing: Research and Practical Aspects. 203-215. (Eds. C. Oropeza et. al. ). Kluwer Academic Publishers. The Netherlands.

Karunaratne, S. and Periyapperuma, K. (1989). Culture of immature embryos of coconut (Cocos nucifera L.) callus proliferation and somatic embryogenesis. Plant Sci. 62: 247:253.

Karunaratne, S. , Gamage, C. and Kovoor, A., (1991). Leaf maturity, a critical factor in embryogenesis. J. Plant Physiol. 139: 27-31.

Rillo, E.P. (1989). A nondestructive technique for collecting immature ce conut inflorescence for tissue culture. Phil. J. Coconut Studies 14(2): 16-17.

Thanh-Tuen, T.N. and De Guzman, E.V. (1983). Formation of pollen embryos in cultured anthers of coconut (Cocos nucifera L. ). Plant Science Letters 29: 81-88.

'Verdeil, J.L. , Huet, C. ; Gtósdemange, F. and Buffard-Morel, J. (1994). Plant regeneration from cultured immature inflorescences of coconut (Cocos nucifera L. ) : Evidence for somatic embryogenesis. Plant Cell Reports 13: 218-221. 